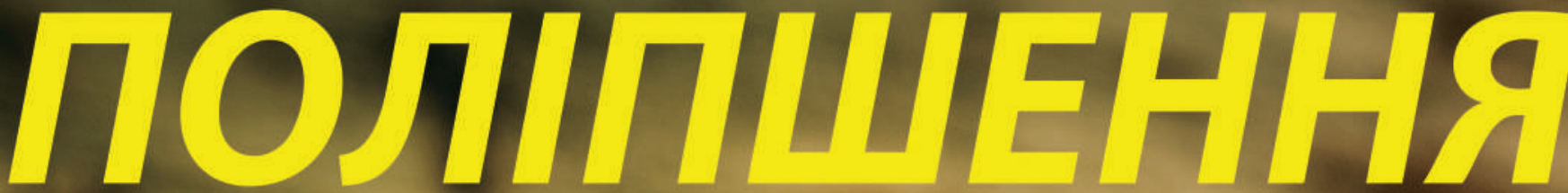
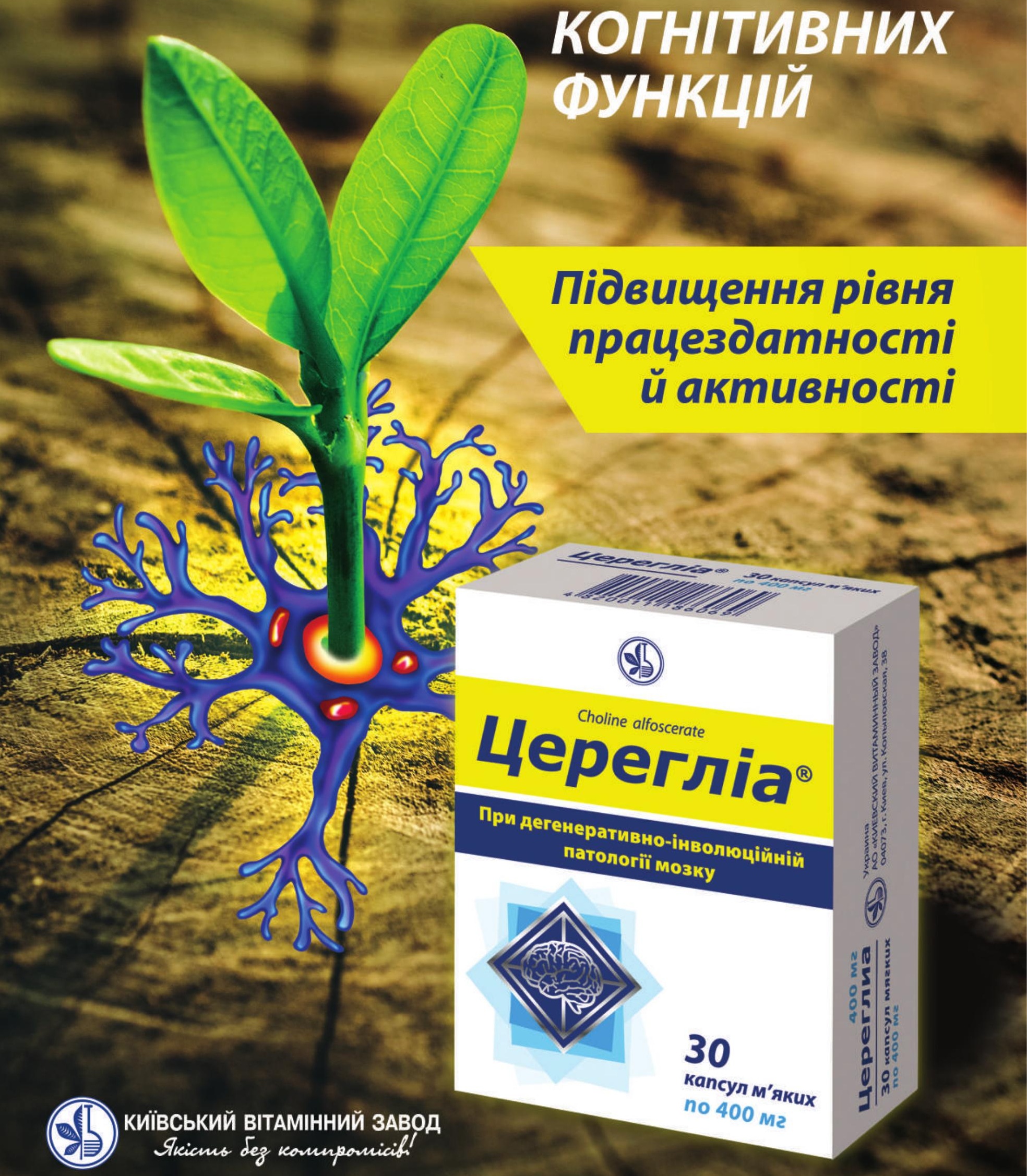

Інформація для медичних і фармацевтичних працівників, а також для поширення в рамках спеціалізованих заходів з медичної тематики.

Реєстраційне посвідчення М03 України № UA/16976/01/01 від 04.10.2018. 


\title{
Лікування когнітивних розладів при депресії, зумовленій цереброваскулярною патологією: можливості впливу на ацетилхолінову нейротрансмісію
}

\author{
Н.О. Марута, І.О. Явдак, О.С. Череднякова \\ Державна установа «Інститут неврології, психіатрії та наркології НАМН України», Харків, Україна
}

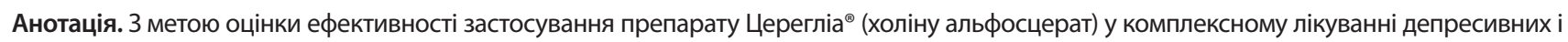
когнітивних розладів у хворих на дисциркуляторну енцефалопатію II стадії, зумовлену атеросклерозом, проведено комплексне клінічне і психодіагностичне обстеження (оцінка депресивного стану за шкалою Гамільтона; мнестичної діяльності за методикою заучування 10 слів А.Р. Лурія; когнітивних функцій за Монреальською шкалою оцінки когнітивних функцій; рівня працездатності, концентрації і стійкості уваги за допомогою коректурної проби Бурдона; ступеня вираженості астенічних розладів за суб'єктивною шкалою оцінки астенії 60 пацієнтів із зазначеною патологією. Результати проведеного дослідження доводять високу ефективність застосування у комплексному лікуванні хворих нейропротекторної терапії препаратом Церегліа ${ }^{\circledR}$. Показано, що додаткове застосування в терапії препарату Церегліа ${ }^{\circledR}$ сприяє редукції депресивних розладів, поліпшенню когнітивних функцій (довільної уваги і мнестичних функцій), підвищенню рівня працездатності й активності, що підтверджує перспективність застосування цього лікарського засобу в терапії даної категорії хворих.

Ключові слова: депресія, когнітивні розлади, нейропротекторна терапія, холіну альфосцерат, Церегліа®.
\end{abstract}

\section{Вступ}

Проблема депресії в сучасній медицині - одна з найактуальніших, що зумовлено високими показниками захворюваності та поширеності цієї патології в усьому світі.

Експерти Всесвітньої організації охорони здоров'я постійно прогнозують зростання поширеності депресії, активно вивчаються соціальні, психологічні, нейробіологічні аспекти, що лежать в основі депресивних станів, формування їх резистентних, схильних до затяжного перебігу форм [1].

Одним з поширених варіантів депресії $\epsilon$ депресивні стани при цереброваскулярній патології, які розвиваються в осіб віком $>45$ років і характеризуються складними коморбідними взаємовідносинами судинної й афективної патології, результатом чого $\epsilon$ анергія, виражений когнітивний дефіцит і прогресивне порушення соціального функціонування, що мають особливо несприятливі медико-соціальні наслідки [2-7].

Наявність в структурі цереброваскулярної патології депресивних розладів створює складнощі в діагностиці і зумовлює потребу в інтенсифікації терапії з урахуванням специфіки стану нейромедіаторів при цій патології [8-11].

Особливої актуальності проблема ефективності лікування цереброваскулярної патології з коморбідною депресією набуває в умовах пандемії COVID-19 [2, 12-17].

Виходячи з сучасних уявлень про патогенез депресивних розладів, які розвиваються при дисциркуляторній енцефалопатії (ДЕ), вельми перспективним $\epsilon$ застосування препаратів, що поліпшують пластичність мозкової тканини та мають нейротрофічні і нейропротекторні властивості $[2,14,18]$.

Одним з таких препаратів, що виявляють нейропротекторний ефект, $\epsilon$ холіну альфосцерат, клінічна ефективність і безпека якого підтверджені результатами низки клінічних досліджень [6, 19-22]. У цих дослідженнях показано, що механізм дії холіну альфосцерату зумовлений можливостями ацетилхоліну як одного з медіаторів центральної нервової системи, що впливає на холінергічну недостатність, при інсульті та черепно-мозковій травмі забезпечує відновлення рухових функцій, при сопорі і комі надає ефект пробудження, а при ДЕ, деменції та хворобі Альцгеймера - відновлює активність і продуктивне мислення.

Ефекти холіну альфосцерату спрямовані передусім на корекцію вищих кіркових функцій: відновлення концентрації уваги і пам'яті, поліпшення розумової і фізичної працездатності, емо- ційного стану хворих, когнітивних функцій. Безсумнівно, важливим аспектом ефективності препарату є сприятливий профіль безпеки і переносимості.

\section{0б'єкт і методи дослідження}

3 метою оцінки терапевтичної ефективності застосування препарату Церегліа ${ }^{\circledR}$ (холіну альфосцерат) у комплексному лікуванні депресивних розладів у хворих із ДЕ ІІ стадії, зумовленою атеросклерозом, проведено обстеження 60 пацієнтів обох

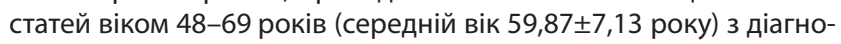
зом «депресивний розлад органічного генезу» (F06.3) відповідно до критеріїв MKX-10.

Діагноз ДЕ II стадії органічного (атеросклеротичного) генезу встановлювали на підставі скарг хворих, даних анамнезу, неврологічного, психіатричного статусів, підтверджених результатами додаткових досліджень (магнітно-резонансна томографія головного мозку, ультразвукова допплерографія магістральних артерій голови, офтальмологічне дослідження, клінічні та біохімічні аналізи крові).

Усі пацієнти випадковим способом були розподілені на основну $(n=38)$ і контрольну $(n=22)$ групи лікування. Додатково до базової терапії (вазоактивні засоби, антидепресанти) пацієнти основної групи отримували препарат Церегліа ${ }^{\circledR}$ (холіну альфосцерат) по 400 мг по 1 капс. 3 рази на добу. Пацієнти контрольної групи отримували базову терапію без застосування препарату Церегліа ${ }^{\circledR}$. Як антидепресивну терапію хворі приймали антидепресанти групи селективних інгібіторів зворотного захоплення серотоніну (есциталопрам, сертралін) і селективні інгібітори зворотного захоплення серотоніну та норадреналіну (венлафаксин пролонгованого вивільнення).

Тривалість лікування і спостереження для кожного пацієнта становила 30 днів.

Усі пацієнти проходили комплексне клінічне обстеження з оцінюванням соматичного, неврологічного, психічного стану і когнітивного функціонування до та після курсу лікування. Психодіагностичне обстеження включало:

- оцінку депресивного стану за оціночною шкалою Гамільтона (Hamilton Depression Rating Scale - HDRS) [23];

- оцінку різних когнітивних функцій (уваги і концентрації, виконавчих функцій, пам'яті, мовлення, оптико-просторової діяльності, концептуального мислення, рахування й орієнта- 
ції) за Монреальською шкалою оцінки когнітивних функцій (Montreal Cognitive Assessment - MoCA) [25];

- визначення рівня працездатності, концентрації і стійкості уваги за допомогою коректурної проби Бурдона [26];

- оцінку особливостей мнестичної діяльності (слухомовної пам'яті): обсягу і швидкості слухомовного запам'ятовування, обсягу відстроченого відтворення, виснаження (стомлюваності) за методикою заучування 10 слів А.Р. Лурія [27];

- оцінку ступеня вираженості астенічних розладів за суб'єктивною шкалою оцінки астенії (Multidimensional Fatigue Inventory - MFI-20) (загальна втома, фізична стомлюваність, розумова стомлюваність, редукція мотивацій і редукція активності) [28].

Статистичне оброблення отриманих даних проводили із застосуванням електронних таблиць «Excel-97» і статистичного пакету «Statistica 6.0» з використанням параметричних і непараметричних методів аналізу даних: t-тесту і точного методу Фішера.

\section{Результати та їх обговорення}

Серед найчастіших неврологічних синдромів на вихідному рівні виявлені: цефалгічний $(81,58 \%$ хворих основної та $81,82 \%$ - контрольної груп), вестибуло-атактичний $(57,89$ та $59,09 \%$ відповідно), підкорковий (23,68 та 22,73\% відповідно) синдроми, екстрапірамідна недостатність (26,32 та 27,27\% відповідно) і сенсорні розлади (21,05 та 22,73\% відповідно).

Депресивні розлади виявлялися насамперед зниженим настроєм (100\% пацієнтів обох груп), апатією, зниженням енергійності, ангедонією $(81,58 \%$ хворих основної та $81,82 \%$ - контрольної груп), порушеннями сну (71,05 та $72,73 \%$ відповідно), порушенням апетиту (68,42 та 63,64\% відповідно), іпохондричними переживаннями $(65,80$ та 68,18\% відповідно) і різними тілесними невизначеними відчуттями («пече», «жалить», «стискає») (47,34 та 45,45\% відповідно), відчуттям напруження і тривожності (68,42 та 63,64\% відповідно).

Важливим складником клінічної картини в обстежених обох груп були когнітивні порушення, які проявлялися в суб'єктивних скаргах на розсіяну увагу, погіршення пам'яті щодо поточних подій (100\% пацієнтів обох груп), зниження розумової працездатності (63,14\% хворих основної та 63,64\% - контрольної груп). У пацієнтів виявлено також ідеомоторну загальмованість, швидке виснаження, зниження швидкості мовлення.

Основні суб'єктивні скарги хворих оцінені в балах (від 0 до 3) до та після проведеного лікування. Отримані дані відображають ідентичність суб'єктивних скарг хворих порівнюваних груп до початку терапії (рис. 1).

Найвищу інтенсивність відмічено щодо суб'єктивних симптомів, як-от «зниження працездатності» $(2,03$ бала у хворих основної та 2,04 - контрольної групи), «слабкість» (1,98 і 1,96 бала

Рисунок 1 Динаміка суб'єктивних скарг обстежених під впливом лікування (в балах)

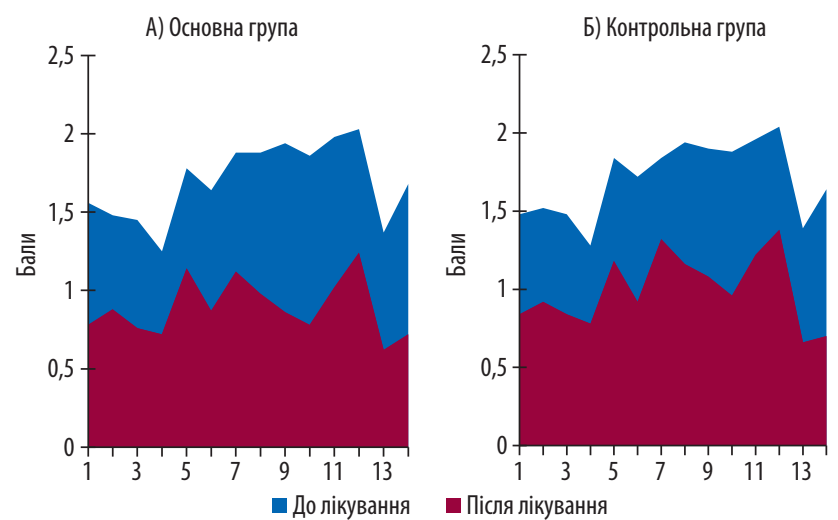

1 - головний біль, 2 - запаморочення, 3 - хиткість, 4 - шум у вухах, 5 - артеріальна гіпертензія, 6 - кардіалгія, 7 - зниження пам'яті, 8 - розсіяна увага, 9 - пригніченість, 10 - апатія, 11 - слабкість, 12 - зниження працездатності, 13 - тривога, 14 - порушення сну. відповідно), «пригніченість» (1,94 і 1,90 бала відповідно), «розсіяна увага» (1,88 і 1,94 бала відповідно), «зниження пам'яті» (1,88 і 1,84 бала відповідно), «апатія» (1,86 і 1,88 бала відповідно).

Після проведеного лікування виражену позитивну динаміку у хворих основної групи спостерігали за всіма оцінюваними симптомами, особливо в оцінці «зниження пам'яті» $(1,12$ бала у хворих основної групи порівняно з 1,32 бала у хворих групи контролю; $\mathrm{p} \leq 0,05)$, «розсіяна увага» $(0,98$ та 1,16 бала відповідно), «слабкість» (1,02 та 1,22 бала відповідно), «зниження працездатності» (1,24 та 1,38 бала відповідно), «пригніченість» $(0,86$ та 1,08 бала відповідно), «апатія» (0,78 та 0,96 бала відповідно).

Оцінювання психоемоційного стану хворих проводили з використанням оціночної шкали HDRS

До початку лікування сумарний бал за шкалою HDRS у хворих досліджуваних груп був ідентичним і знаходився в діапазоні 15-20 балів (середній бал в основній групі - 17,45, в контрольній - 17,41), що відповідало «середньому» рівню депресії.

Динаміка вираженості депресивної симптоматики, за даними шкали HDRS, у обстежених під впливом терапії (рис. 2) свідчить, що в процесі лікування вираженість депресивної симптоматики зменшувалася у хворих обох груп: середній показник за шкалою HDRS на 30-й день лікування в основній групі становив 9,12, в контрольній - 10,44 бала, що відображає зменшення вираженості симптомів депресії у хворих обох груп до «легкого» рівня.

Відсутності змін в показниках депресії за шкалою HDRS під впливом 30-денної терапії в порівнюваних групах не виявлено, що узгоджується з динамікою показників суб'єктивних скарг хворих оцінюваних груп.

Водночас регрес депресивної симптоматики у хворих основної групи був більш вираженим ( $\mathrm{p} \leq 0,05)$.

Розглядаючи динаміку показників HDRS за окремими пунктами, слід зазначити, що у хворих основної групи поліпшення показників депресії порівняно з групою контролю відбувалося переважно за пунктами «депресивний настрій» (з 2,01 до 0,97 бала; p $\leq 0,04)$, «працездатність і активність» (з 1,74 до 0,82 бала; $p \leq 0,03)$, «загальмованість» (з 1,64 до 0,68 бала; $\mathrm{p} \leq 0,03$ ), тоді як у хворих контрольної групи динаміка за цими пунктами шкали HDRS була достовірно нижчою.

Отримані дані демонструють також взаємозв'язок вираженості депресивної симптоматики у пацієнтів обох груп із соматичним станом та іпохондричною фіксацією на ньому (достовірно позитивна динаміка в процесі терапії і редукція депресії за пунктами шкал HDRS «загальні соматичні симптоми» (3 1,48 до 0,84 бала (ps0,05) у хворих основної групи і з 1,44 до 1,02 бала $(p \leq 0,04)$ у хворих групи контролю) та «іпохондрія» (3 1,58 до 0,81 бала $(p \leq 0,02)$ у хворих основної групи і з 1,49 до 0,96 бала (p $\leq 0,04)$ у хворих групи контролю)

Для оцінювання стану і динаміки когнітивних функцій в обстежених пацієнтів використовували шкалу МоСА (табл. 1).

Таблиця 1 Оцінка стану когнітивних функцій до і після лікування в групах обстежених

\begin{tabular}{lcccc}
\hline \multirow{1}{*}{ Параметри оцінки } & \multicolumn{2}{c}{ Основна група, $\mathbf{n = 3 8}$} & Контрольна група, $\mathbf{n = 2 2}$ \\
\cline { 2 - 5 } & $\begin{array}{c}\text { До } \\
\text { лікування }\end{array}$ & $\begin{array}{c}\text { Після } \\
\text { лікування }\end{array}$ & $\begin{array}{c}\text { До } \\
\text { лікування }\end{array}$ & $\begin{array}{c}\text { Після } \\
\text { лікування }\end{array}$ \\
\hline $\begin{array}{l}\text { Зорово-конструктивні/ } \\
\text { виконавські навички }\end{array}$ & $4,5 \pm 0,57$ & $4,8 \pm 0,61$ & $4,5 \pm 0,53$ & $4,7 \pm 0,56$ \\
\hline Номінативна функція мовлення & $3,0 \pm 0,00$ & $3,0 \pm 0,00$ & $3,0 \pm 0,00$ & $3,0 \pm 0,00$ \\
\hline Пам'ять & $3,6 \pm 0,46$ & $4,5 \pm 0,53^{*}$ & $3,8 \pm 0,48$ & $4,2 \pm 0,51$ \\
\hline Увага & $4,3 \pm 0,51$ & $5,3 \pm 0,67^{*}$ & $4,2 \pm 0,53$ & $4,7 \pm 0,63$ \\
\hline Швидкість мовлення & $2,6 \pm 0,31$ & $2,6 \pm 0,34$ & $2,7 \pm 0,27$ & $2,8 \pm 0,36$ \\
\hline Абстрактне мислення & $1,6 \pm 0,31$ & $1,8 \pm 0,33$ & $1,6 \pm 0,26$ & $1,6 \pm 0,31$ \\
\hline Орієнтація & $5,8 \pm 0,42$ & $5,9 \pm 0,35$ & $5,7 \pm 0,4$ & $5,9 \pm 0,3$ \\
\hline Загальний бал за шкалою & $25,4 \pm 3,16$ & $27,9 \pm 2,95^{*}$ & $25,5 \pm 3,21$ & $26,9 \pm 3,32$ \\
\hline
\end{tabular}

Статистично достовірні відмінності в оцінках до і після лікування за групами дослідження: ${ }^{*} p<0,05$. Дані наведені в такому форматі: середнє арифметичне \pm стандартне відхилення середнього арифметичного $(\mathrm{M} \pm \sigma)$. 
Результати, отримані в групах обстежених до лікування, загалом схожі: пацієнти обох груп характеризувалися зниженням когнітивного функціонування (оцінка когнітивного функціонування за шкалою МоСА в основній групі становила $25,4 \pm 3,16$, в контрольній $-25,5 \pm 3,21$ бала). За окремими параметрами оцінки зниження когнітивного функціонування виявлялося насамперед через порушення пам'яті, уваги і виконавчих функцій. За результатами проведеного лікування у пацієнтів обох груп відмічали позитивну динаміку когнітивної продуктивності, рівень якої відповідав нормативному. Водночас з цим в основній групі пацієнтів відзначали статистично достовірне поліпшення рівня когнітивного функціонування (з 25,4 33,16 бала при ініці-

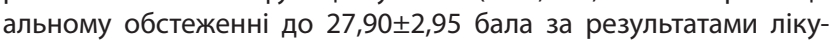
вання; $p \leq 0,05)$. Також після лікування в основній групі значуще

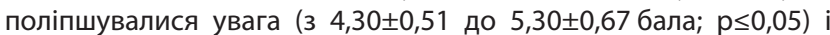

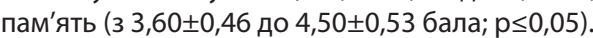

У пацієнтів контрольної групи когнітивна продуктивність в результаті проведеного лікування також підвищувалася, про-

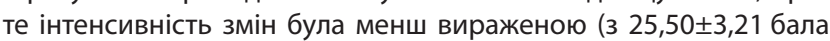

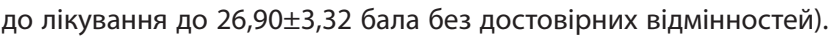
За загальним рівнем функціонування когнітивних процесів, а також за окремими когнітивними функціями статистично достовірної динаміки під впливом лікування в контрольній групі не виявлено.

Динаміка когнітивного функціонування в групах обстежених під впливом лікування (рис. 3) свідчить, що у хворих основної групи відмічено достовірно більш виражене поліпшення когнітивного функціонування під впливом терапії ( $\mathrm{d}_{\text {моса }}=-2,50 \pm 0,38$ бала) порівняно 3 контрольною групою ( $\mathrm{d}_{\text {моса }}=-1,40 \pm 0,38$ бала); $\mathrm{p} \leq 0,05$. Достовірно більш виражене поліпшення у пацієнтів основної групи виявлено за такими параметрами: концентрація уваги і пам'ять $(-1,0 \pm 0,16$ і 0,9 90,13 бала) при порівнянні 3 контрольною групою $(-0,5 \pm 0,1 \mathrm{i}-0,4 \pm 0,12$ бала); $\mathrm{p} \leq 0,05$.
Таблиця 2 Оцінка функцій довільної уваги до і після лікування в групах обстежених

\begin{tabular}{lcccc}
\hline & \multicolumn{2}{c}{ Основна група, $\mathbf{n = 3 8}$} & Контрольна група, $\mathbf{n = 2 2}$ \\
\cline { 2 - 5 } Параметри оцінки (в балах) & $\begin{array}{c}\text { До } \\
\text { лікування }\end{array}$ & $\begin{array}{c}\text { Після } \\
\text { лікування }\end{array}$ & $\begin{array}{c}\text { До } \\
\text { лікування }\end{array}$ & $\begin{array}{c}\text { Після } \\
\text { лікування }\end{array}$ \\
\hline $\begin{array}{l}\text { S (швидкість роботи/ } \\
\text { продуктивність) }\end{array}$ & $13,34 \pm 1,76$ & $17,23 \pm 2,11^{*}$ & $12,97 \pm 1,68$ & $15,37 \pm 1,83$ \\
\hline $\begin{array}{l}\text { К (концентрація уваги/точність } \\
\text { виконання) }\end{array}$ & $11,75 \pm 1,65$ & $17,49 \pm 2,32^{* *}$ & $12,27 \pm 2,13$ & $15,82 \pm 2,41^{*}$ \\
\hline Стійкість уваги & $9,25 \pm 1,12$ & $12,76 \pm 1,83^{*}$ & $9,12 \pm 0,94$ & $11,23 \pm 1,75$ \\
\hline
\end{tabular}

Статистично достовірні відмінності в оцінках до і після лікування за групами дослідження: ${ }^{*} p \leq 0,05,{ }^{* *} p \leq 0,01$. Дані наведені в такому форматі: середнє арифметичне \pm стандартне відхилення середнього арифметичного (M $\pm \sigma)$.

Тобто згідно з отриманими даними у пацієнтів основної групи зафіксовано більш інтенсивне поліпшення когнітивного функціонування, зокрема функцій довільної уваги і пам'яті, більш докладний аналіз яких став наступним етапом дослідження.

Для дослідження функції уваги, ії продуктивності, стійкості та концентрації використовували коректурну пробу Бурдона.

Отримані дані у групах дослідження в порівняльному аспекті до та після проведеної терапії наведені в табл. 2.

Згідно з наведеними даними вихідний рівень (до початку лікування) показників параметрів працездатності у пацієнтів обох досліджуваних груп достовірно не відрізнявся. За результатами лікування в обох групах відмічена позитивна динаміка в показниках працездатності. Водночас з цим в основній групі пацієнтів позитивна динаміка за результатами терапії підтверджувалася статистично за всіма параметрами: відзначалося достовірне підвищення показників продуктивності (швидкості переробки

Рисунок 2 Динаміка вираженості депресії в обстежених за даними шкали HDRS під впливом терапії

Основна група

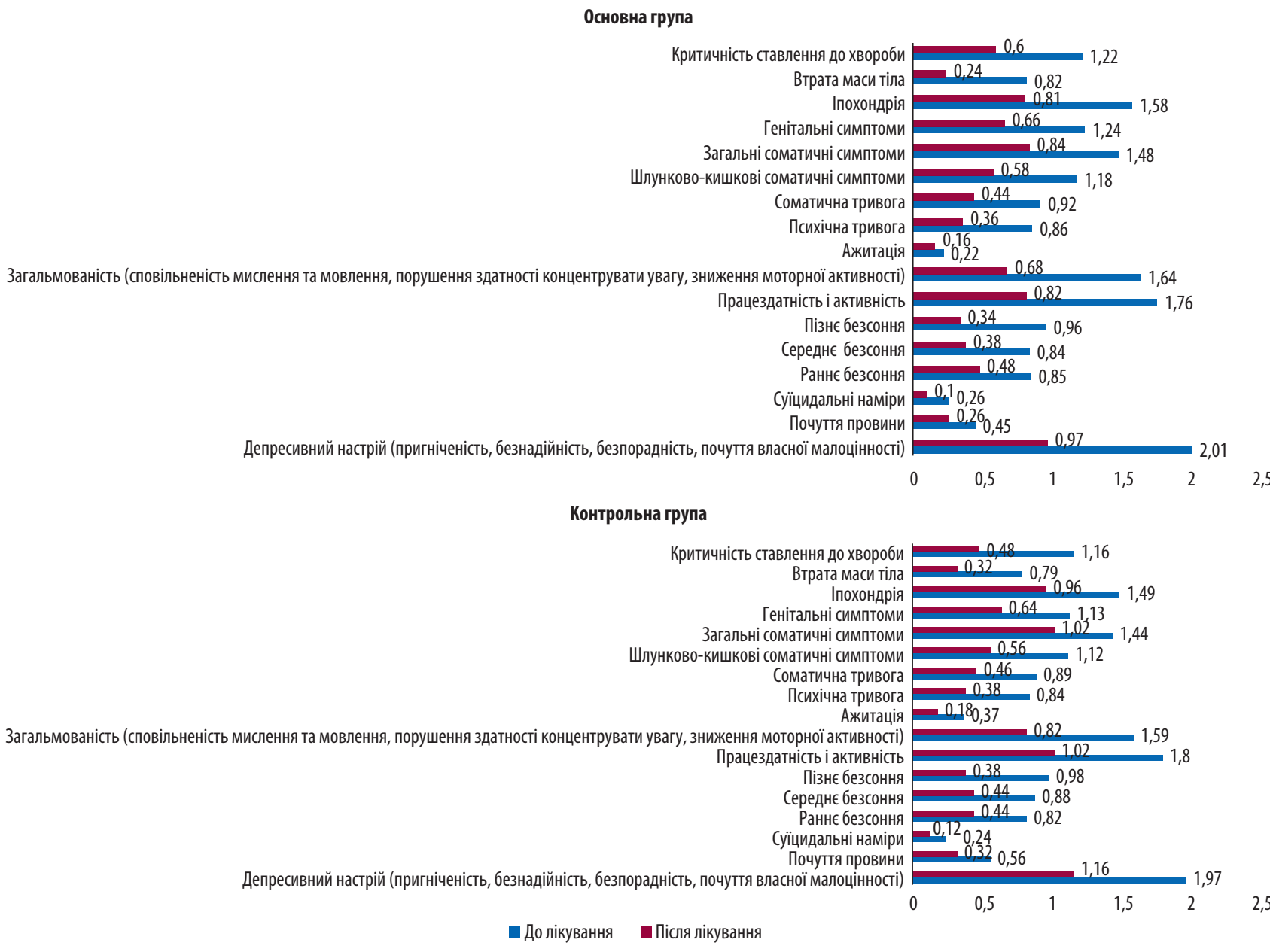


Рисунок 3 Динаміка когнітивного функціонування під впливом терапії в групах обстежених (оцінка за шкалою МоСа)

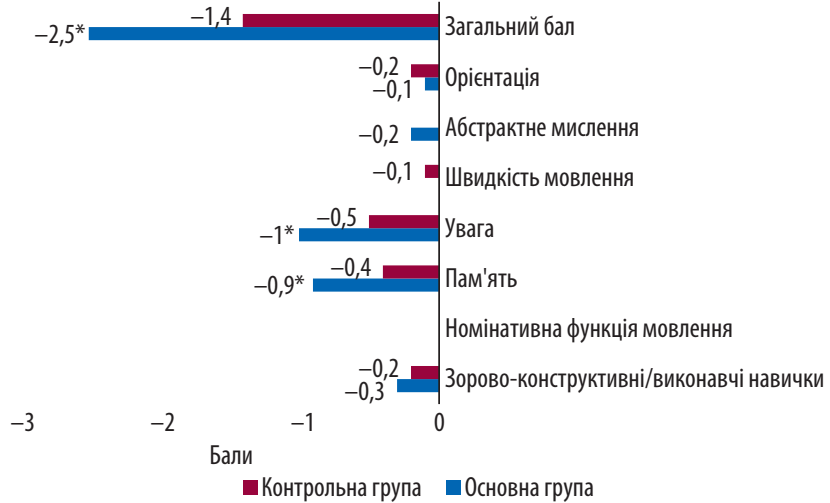

* Статистично достовірні відмінності між основною і контрольною групою дослідження: $p \leq 0,05$.

Рисунок 4 Динаміка показників працездатності в основній групі дослідження під впливом лікування

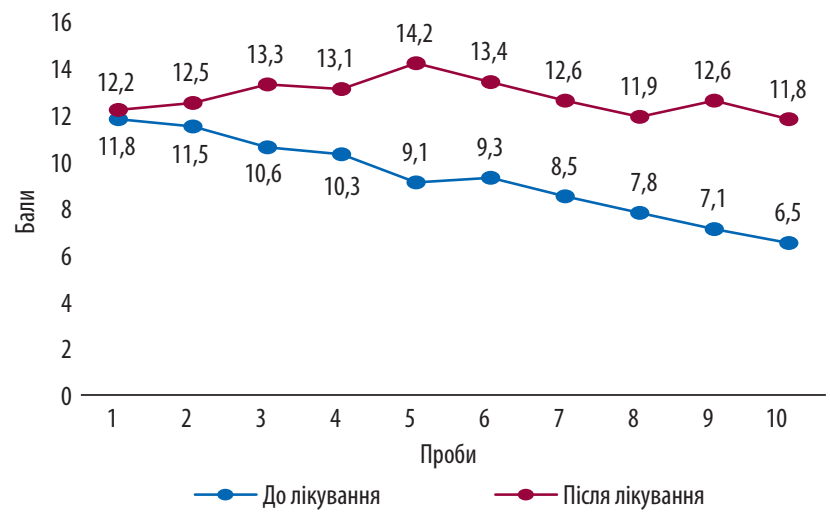

Рисунок 5 Динаміка показників працездатності в контрольній групі дослідження під впливом лікування

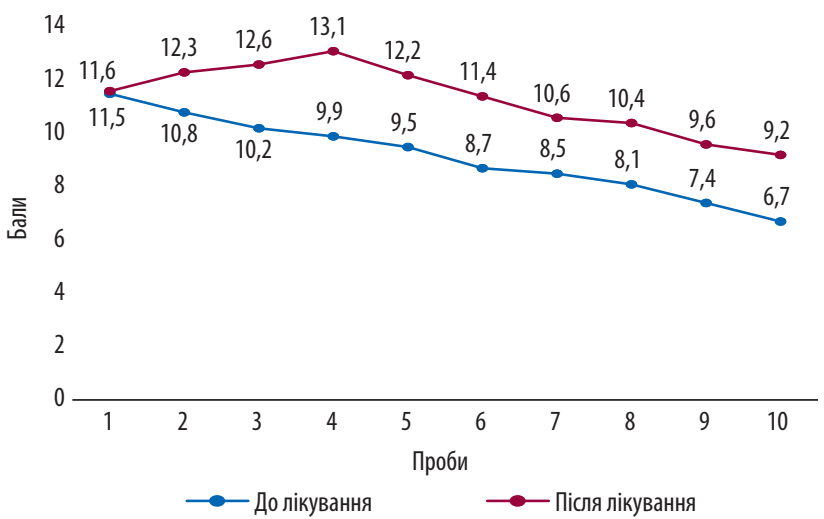

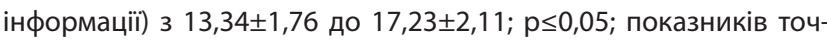

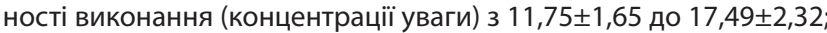
$\mathrm{p} \leq 0,01$ і стійкості уваги з 9,25 $\pm 1,12$ до $12,76 \pm 1,83 ; \mathrm{p} \leq 0,05$. У контрольній групі також відзначено позитивну динаміку, яка виражалася поліпшенням функцій довільної уваги, зокрема фіксували

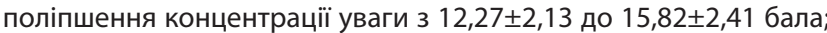
$\mathrm{p} \leq 0,05$. Щодо решти параметрів, як-от продуктивність і стійкість, статистично достовірних змін у пацієнтів контрольної групи не виявлено. Отже, за результатами терапії обстежені пацієнти обох груп характеризувалися наявними позитивними змінами, які полягали у поліпшенні концентрації уваги, до того ж в основній групі ці зміни були більш вираженими і доповнювалися підвищенням загальної продуктивності і стійкості уваги. Тобто у хворих основної групи відзначали підвищення працездатності завдяки збільшенню швидкості та якості обробки інформації, тоді як у хворих контрольної групи значуще підвищувалася лише концентрація уваги.

Співвідношення показників стійкості уваги в процесі виконання проби Бурдона дає змогу судити про рівень і характер працездатності пацієнтів у групах обстежених (рис. 4, 5).

Згідно з отриманими результатами у хворих основної та контрольної груп до початку лікування крива працездатності характеризувалася максимальними показниками на початку роботи з поступовим її зниженням в процесі виконання і максимально низькими показниками на останніх пробах, що свідчило про зниження уваги і збільшення вираженості ознак втоми. Після лікування у хворих обох груп рівень працездатності підвищувався порівняно з вихідним і характеризувався поступовим підвищенням в середині дослідження (на 3-5 пробах), що свідчило про поступове впрацьовування обстежуваних, збільшення точності і швидкості виконання завдання в процесі тестування.

Водночас з цим крива працездатності основної групи характеризувалася відносною стабільністю, підвищення продуктивності стабілізувалося в процесі виконання завдання з досягненням її максимальних величин в середині роботи і збереженням початкового рівня до кінця виконання завдання, що свідчило про відсутність ознак стомлюваності і стабільний рівень працездатності.

У контрольній групі відмічено поступове підвищення показників працездатності до середини роботи, але до кінця тестування відзначалося зниження продуктивності, яке свідчило про поступове виснаження функцій уваги в процесі виконання завдання

Порівняльний аналіз співвідношення динаміки показників працездатності (різниці середніх величин даних до та після лікування) в основній і контрольній групах дає змогу зафіксувати достовірно більш виражене поліпшення довільної уваги, її продуктивності $(-3,89 \pm 0,57$ бала), концентрації $(-5,74 \pm 0,75$ бала) і стійкості $(-3,51 \pm 0,62$ бала) у пацієнтів основної групи порівняно з контрольною групою, де також виявлено позитивну динаміку, але значуще меншої вираженості $(-2,4 \pm 0,45 ;-3,55 \pm 0,52$ i $-2,4 \pm 0,39$ відповідно; $\mathrm{p} \leq 0,05$ ) (рис. 6).

Отримані дані свідчать про підвищення рівня працездатності і поліпшення функцій довільної уваги в процесі терапії в обох групах пацієнтів, водночас з цим в основній групі ці зміни $є$ більш вираженими.

Для оцінювання особливостей мнестичної діяльності використовували методику заучування 10 слів (А.Р. Лурія), вивчали обсяг короткочасного слухо-мовного запам'ятовування, обсяг відстроченого відтворення і виснаженість (стомлюваність) мнестичних функцій. Отримані результати графічно наведені на рис. 7 та 8.

Обсяги короткочасної слухомовної пам'яті на ініціальному етапі обстеження у пацієнтів основної групи становили $6,3 \pm 0,87$ слів, в контрольній $-6,5 \pm 1,1$. До лікування крива

Рисунок 6 Динаміка працездатності під впливом терапії в групах обстежених (проба Бурдона)

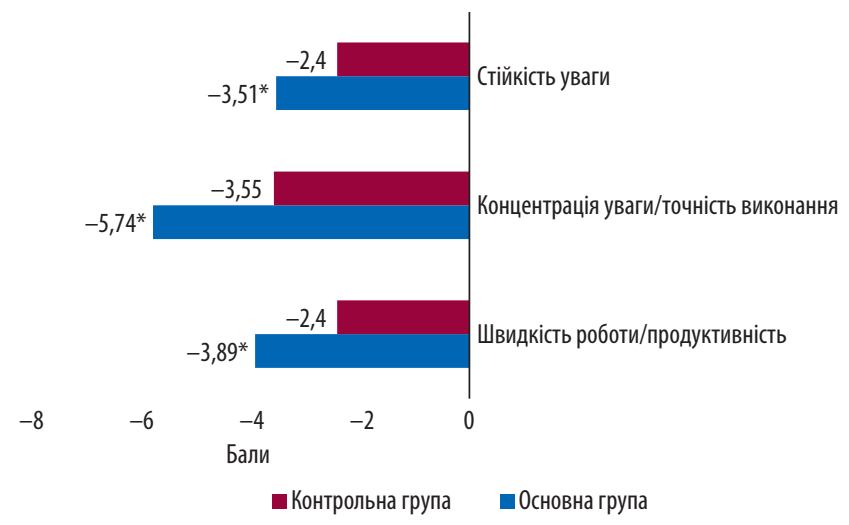

Статистично достовірні відмінності між основною і контрольною групою дослідження: ${ }^{*} \mathrm{p} \leq 0,05$. 
Рисунок 7 Динаміка показників мнестичної діяльності у пацієнтів основної групи під впливом лікування (методика заучування 10 слів А.Р. Лурія)

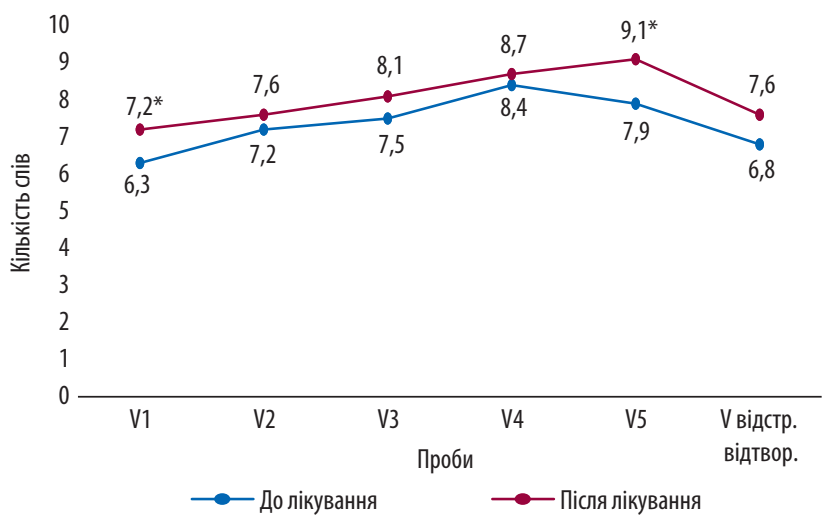

Статистично достовірні відмінності між основною і контрольною групою дослідження: ${ }^{*} \mathrm{p} \leq 0,05$.

Рисунок 8 Динаміка показників мнестичної діяльності у пацієнтів контрольної групи під впливом лікування (методика заучування 10 слів А.Р. Лурія)

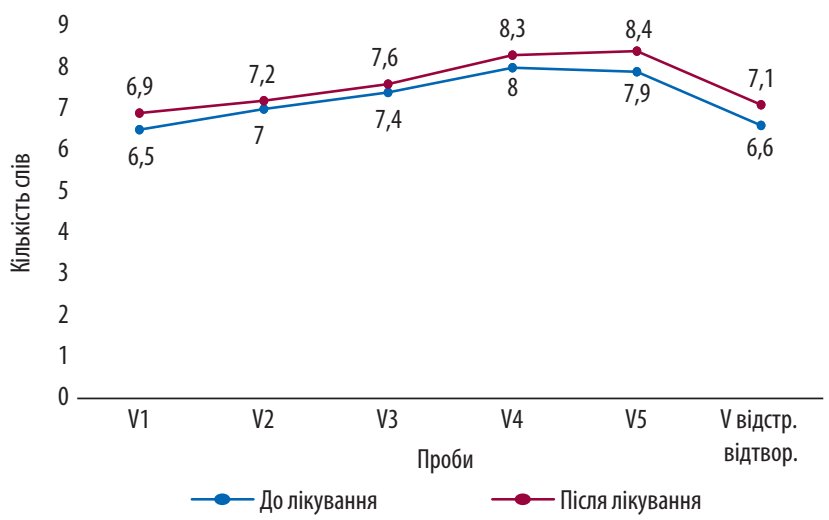

Рисунок 9 Динаміка показників мнестичних функцій після лікування в групах обстежених (методика заучування 10 слів А.Р. Лурія)

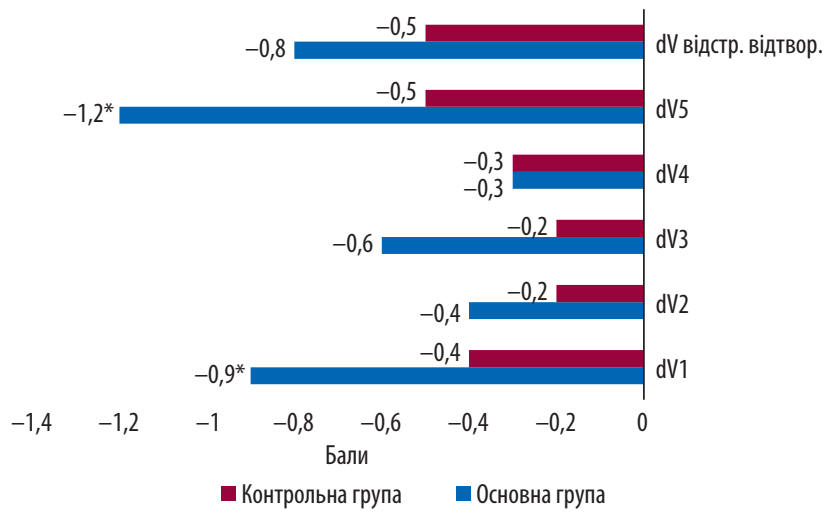

запам'ятовування пацієнтів обох груп характеризувалася поступовим збільшенням обсягів запам'ятовування і їх зменшенням на 5-й пробі, що свідчило про стомлюваність і виснаження мнестичних функцій. За підсумками лікування у пацієнтів основної групи відзначалося достовірне поліпшення показників обсягів

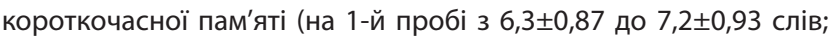
$\mathrm{p} \leq 0,05$ ) і поступове їх збільшення з кожною наступною пробою, з досягненням максимуму на 5-й пробі, обсяги запам'ятовування на якій також достовірно збільшилися порівняно з вихідними да-

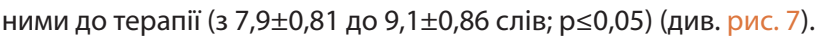

У хворих контрольної групи також виявлено поліпшення показників мнестичних функцій, проте їх вираженість не до- сягала рівня статистичної значущості (див. рис. 8). Крива запам'ятовування у пацієнтів контрольної групи за своїм характером була ідентична ініціальним даним, але 3 дещо вищим рівнем обсягів запам'ятовування. Крива запам'ятовування у цих пацієнтів характеризувалася наявним ефектом плато на 4-5-й пробах.

Аналіз показників мнестичних функцій до та після лікування в основній і контрольній групах наведений на рис. 9.

Отримані дані підтверджують більш виражену позитивну динаміку мнестичних функцій в основній групі. Зокрема, у пацієнтів основної групи відзначали достовірно більш виражене поліпшення короткочасної пам'яті на 1-й пробі $\left(\mathrm{dV}_{1}=-0,9 \pm 0,14\right)$ порівняно 3 контрольною групою $\left(\mathrm{dV}_{1}=-0,4 \pm 0,1\right) ; \mathrm{p} \leq 0,05$; і на 5-й пробі $\left(\mathrm{dV}_{5}=-1,20 \pm 0,21 \mathrm{i} \mathrm{dV}_{5}=-0,5 \pm 0,11 ; \mathrm{p} \leq 0,05\right.$ відповідно). На рівні тенденції більш виражена позитивна динаміка обсягів пам'яті у пацієнтів основної групи відзначалася також на 2-й і 3-й пробах і за результатами відстроченого відтворення, однак статистичні відмінності були недостовірними.

Динаміка когнітивного функціонування у пацієнтів з депресивними розладами органічного генезу свідчить про значне його поліпшення під впливом лікування, що підтверджується позитивною динамікою показників обсягів, точності і продуктивності довільної уваги, а також збільшенням обсягів пам'яті і її стійкості.

Для об'єктивізації та аналізу ступеня вираженості астенічної симптоматики і її динаміки під впливом терапії використовували шкалу MFI-20, отримані дані наведені в табл. 3.

Аналіз вихідних показників вираженості астенії у пацієнтів обох груп на початковому етапі лікування показав наявність підвищених інтегральних показників астенічної симптоматики, переважно через високі бали за шкалами загальної астенії, зниженої активності і фізичної астенії, що свідчило про їх підвищену стомлюваність, слабкість, низьку переносимість навантажень і напруження.

У динаміці відбувалася редукція астенічних симптомів у обох групах обстежених за всіма наявними в методиці шкалами і за інтегральним показником. Водночас в основній групі пацієнтів вираженість астенічної симптоматики зменшувалася за більшою кількістю шкал, ніж у контрольній. Зокрема, в основній групі відзначали статистично достовірне виражене зниження рівня фі-

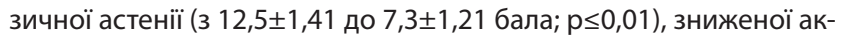

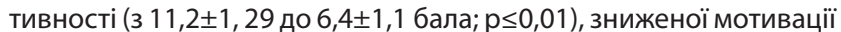

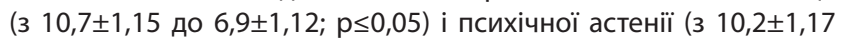
до 6,2 $\pm 1,17$ бала; $p \leq 0,05)$, що позначалося на статистично достовірних змінах рівня інтегрального показника астенії (3 11,4士1,37

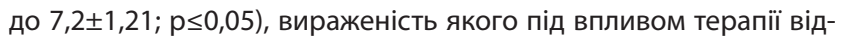
повідала середньому ступеню.

У контрольній групі зниження астенічних проявів було менш вираженим. Статистично достовірна редукція фіксувала-

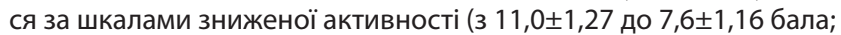

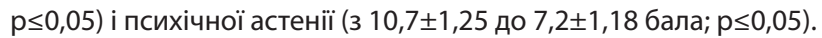

Аналіз динаміки астенічної симптоматики (різниці середніх величин даних до і після лікування) підтверджує більш ви-

Таблиця 3 Оцінка астенії до та після лікування в групах обстежених (шкала MFI-20)

\begin{tabular}{lcccc}
\hline \multirow{2}{*}{$\begin{array}{c}\text { Параметри оцінки (в балах) } \\
\text { Загальна астенія }\end{array}$} & \multicolumn{2}{c}{ Основна група, $\mathbf{n = 3 8}$} & Контрольна група, $\mathbf{n = 2 2}$ \\
\cline { 2 - 5 } & $\begin{array}{c}\text { До } \\
\text { лікування }\end{array}$ & $\begin{array}{c}\text { Після } \\
\text { лікування }\end{array}$ & $\begin{array}{c}\text { До } \\
\text { лікування }\end{array}$ & $\begin{array}{c}\text { Після } \\
\text { лікування }\end{array}$ \\
\hline Знижена активність & $12,4 \pm 1,35$ & $9,8 \pm 1,13$ & $11,9 \pm 1,33$ & $10,4 \pm 1,24$ \\
\hline Зниження мотивації & $11,2 \pm 1,29$ & $6,4 \pm 1,1^{* *}$ & $11,0 \pm 1,27$ & $7,6 \pm 1,16^{*}$ \\
\hline Фізична астенія & $10,7 \pm 1,15$ & $6,9 \pm 1,12^{*}$ & $9,9 \pm 1,18$ & $7,5 \pm 1,19$ \\
\hline Психічна астенія & $12,5 \pm 1,41$ & $7,3 \pm 1,21^{* *}$ & $11,8 \pm 1,34$ & $8,7 \pm 1,22$ \\
\hline Інтегральний показник & $10,2 \pm 1,17$ & $6,2 \pm 1,17^{*}$ & $10,7 \pm 1,25$ & $7,2 \pm 1,18^{*}$ \\
\hline Параметри оцінки (в балах) & $11,4 \pm 1,37$ & $7,2 \pm 1,21^{*}$ & $11,1 \pm 1,31$ & $8,3 \pm 1,26$ \\
\hline
\end{tabular}

Статистично достовірні відмінності в оцінках до і після лікування за групами дослідження: ${ }^{*} p \leq 0,05,{ }^{* *} p \leq 0,01$. Дані наведені в такому форматі: середнє арифметичне \pm стандартне відхилення середнього арифметичного $(\mathrm{M} \pm \sigma)$. 
Рисунок 10 Динаміка астенічних проявів під впливом терапії в групах обстежених (шкала MFI-20)

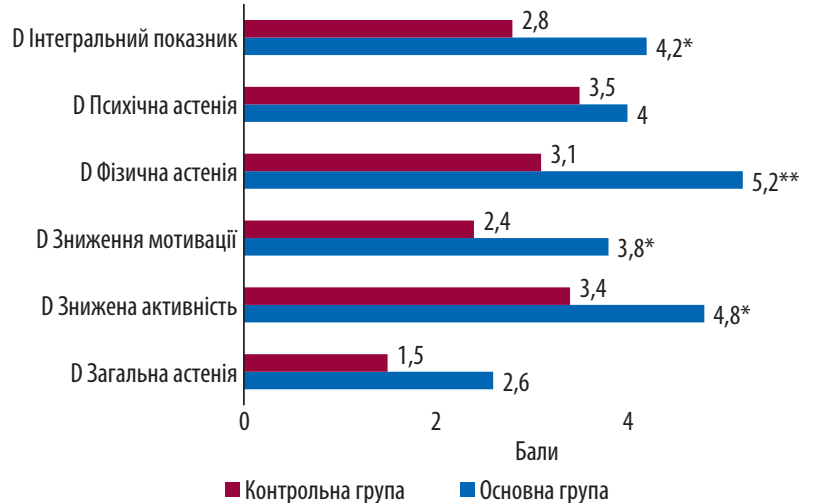

Статистично достовірні відмінності між основною і контрольною групою дослідження: ${ }^{*} \mathrm{p} \leq 0,05,{ }^{* *} \mathrm{p} \leq 0,01$.

ражену позитивну динаміку астенії під впливом лікування у пацієнтів основної групи. Так, в основній групі відзначали достовірно більш виражене зниження фізичних проявів астенії $(5,2 \pm 0,73$ бала порівняно 3 контрольною групою $3,1 \pm 0,53$ бала; $\mathrm{p} \leq 0,01)$, підвищення рівня активності $(4,8 \pm 0,61$ та 3,4 $\pm 0,48$ бала відповідно; $\mathrm{p} \leq 0,05)$, підвищення рівня мотивації $(3,8 \pm 0,55$ та $2,4 \pm 0,41$ бала відповідно; $p \leq 0,05)$, а також більш виражену редукцію інтегрального показника за шкалою астенії $(4,2 \pm 0,54$ та

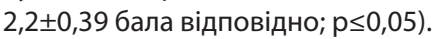

Отримані результати свідчать про більш виражений терапевтичний ефект щодо редукції астенічної симптоматики у пацієнтів основної групи.

\section{Висновок}

Результати проведеного дослідження демонструють, що застосування препарату Церегліа ${ }^{\circledR}$ в терапії депресивних розладів при ДЕ судинного генезу сприяє досягненню більш вираженого терапевтичного ефекту і позитивно впливає на редукцію когнітивної симптоматики та астенічних проявів.

Отримані в процесі порівняльного аналізу статистично достовірні показники динаміки досліджуваних когнітивних функцій і астенічних проявів (середні величини різниць показників до і після лікування) можна розглядати як симптоми-мішені для призначення препарату Церегліа ${ }^{\circledast}$ при зазначеній патології (табл. 4).

Як свідчать наведені дані, симптомами-мішенями, редукцію яких забезпечує додаткове застосування в комплексній терапії

Таблиця 4 Симптоми-мішені дії Церегліа ${ }^{\circledR}$ в терапії пацієнтів із депресивними розладами судинного генезу

\begin{tabular}{|c|c|c|c|c|}
\hline $\begin{array}{l}\text { Симптом- } \\
\text { мішень }\end{array}$ & Показник редукції & $\begin{array}{c}\text { Основна } \\
\text { група }\end{array}$ & $\begin{array}{c}\text { Контрольна } \\
\text { група }\end{array}$ & p \\
\hline \multicolumn{5}{|c|}{ Когнітивне функціонування (шкала МоСА) } \\
\hline $\begin{array}{l}\text { Зниження рівня } \\
\text { когнітивного } \\
\text { функціонування }\end{array}$ & $d(M o C A)$ & $-2,5 \pm 0,38$ & $-1,4 \pm 0,38$ & $\leq 0,05$ \\
\hline \multicolumn{5}{|c|}{ Параметри працездатності (проба Бурдона) } \\
\hline \multirow[t]{3}{*}{ Зниження уваги } & d продуктивність & $-3,89 \pm 0,57$ & $-2,4 \pm 0,45$ & $\leq 0,05$ \\
\hline & d концентрація & $-5,74 \pm 0,75$ & $-3,55 \pm 0,52$ & $\leq 0,05$ \\
\hline & d стійкість & $-3,51 \pm 0,62$ & $-2,4 \pm 0,39$ & $\leq 0,05$ \\
\hline \multicolumn{5}{|c|}{ Параметри мнестичної діяльності (проба 10 слів) } \\
\hline Зниження пам'яті & d обсяг короткочасної пам'яті & $-1,2 \pm 0,21$ & $-0,5 \pm 0,11$ & $\leq 0,01$ \\
\hline \multicolumn{5}{|c|}{ Астенічні прояви (шкала MFI-20) } \\
\hline \multirow[t]{4}{*}{ Астенічні прояви } & d фізична астенія & $5,2 \pm 0,73$ & $3,1 \pm 0,53$ & $\leq 0,01$ \\
\hline & d рівень активності & $4,8 \pm 0,61$ & $3,4 \pm 0,48$ & $\leq 0,05$ \\
\hline & d рівень мотивації & $3,8 \pm 0,55$ & $2,4 \pm 0,41$ & $\leq 0,05$ \\
\hline & d інтегральний показник астенії & $4,2 \pm 0,54$ & $2,2 \pm 0,39$ & $\leq 0,05$ \\
\hline
\end{tabular}

хворих на депресивні розлади при ДЕ судинного генезу препарат Церегліа ${ }^{\oplus}, \epsilon$ знижений рівень загального когнітивного функціонування, зниження пам'яті і концентрації уваги, зниження точності і продуктивності діяльності, астенічні прояви.

Загалом результати проведеного дослідження доводять високу ефективність застосування в комплексній терапії хворих на депресивні розлади при ДЕ судинного генезу нейропротекторної терапії препаратом Церегліа® .

Описана динаміка когнітивних функцій та астенічної симптоматики цілком пояснюється механізмом дії препарату ЦерегліаФ ${ }^{\oplus}$, кий базується на розщепленні холіну альфоцерату в організмі людини під впливом ферментів на холін і гліцерофосфат. При цьому холін бере участь в біосинтезі ацетилхоліну 一 одного з основних медіаторів нервового збудження, а гліцерофосфат $\epsilon$ попередником фосфоліпідів (фосфатидилхоліну) нейронних мембран. У такий спосіб Церегліа ${ }^{\circledR}$ покращує передачу нервових імпульсів в холінергічних нейронах, позитивно впливає на пластичність нейрональних мембран і функцію рецепторів, що зумовлює посилення церебрального кровотоку, метаболічних процесів головного мозку, активацію структур ретикулярної формації.

Додаткове застосування в терапії препарату Церегліа ${ }^{\circledR}$ сприяє більш вираженій редукції депресивних розладів (за рахунок мотиваційного компоненту) і поліпшенню когнітивних функцій (довільної уваги і мнестичних функцій), підвищенню рівня працездатності й активності, що підтверджує перспективність застосування препарату в терапії цієї категорії хворих.

\section{Список використаної літератури/References:}

1. В03 (2015) Всемирный доклад о старении и здоровье (rgnkc.ru/images/pdf_documets/ V0Z_doklad_starenie.pdf).

2. Васенина Е.Е., Левин 0.С., Сонин А.Г. (2017) Современные тенденции в эпидемиологии деменции и ведении пациентов с когнитивными нарушениями. Журн. неврол. психиатр., 117(6-2): 87-95. DOI: 10.17116/jnevro20171176287-95.

3. Гусев Е.И., Боголепова А.Н. (2013) Когнитивные нарушения при цереброваскулярных заболеваниях. МЕДпресс-информ, Москва, $176 \mathrm{c}$

4. Круглов Л.С., Мешандин И.А. (2012) Оптимизация терапии пожилых больных с коморбидностью депрессии и психоорганических нарушений сосудистого генеза. Психиатр. Психофармакотер., 14(2): 40-45

5. Мешандин И.А. (2012) Динамика клинических характеристик и социального функционирования в процессе терапии больных позднего возраста с сочетанием депрессивного расстройства и психоорганических нарушений сосудистого генеза. Автореф. дис. ... канд. мед. наук, Санкт-Петербург, 194 с.

6. Одинак М.М., Емелин А.Ю., Лобзин В.Ю., Колчева Ю.А. (2009) Терапия сосудистых когнитивных расстройств. РМЖ, 20(359): 1295-1297.

7. Taqui AM, Itrat A, QidwaiW, Qadri Z. Depression in the elderly: does family system play a role? A cross-sectional study. BMC Psychiatry. 2007; 7:7-57.

8. Вознесенская Т.Г. (2009) Депрессия в пожилом возрасте. Consilium medicum, 11(2): 74-79.

9. Чистик Т. (2015) Холинергическая стратегия в лечении когнитивных нарушений при старении. Междунар. неврол. журн., 2(72): 147-152.

10. Alexopoulos G.S., Murphy C.F., Gunning-Dixon F.M. et al. (2008) Microstructural white matter abnormalities and remission of geriatric depression. Am. J. Psychiatr., 165: 238-244.

11. Cumming T.B., Bernhardt J., Linden T. (2011) The Montreal cognitive assessment short cognitive evaluation in a large stroke trial. Stroke, 42: 2642-2644.

12. Захаров В.В., Яхно Н.Н. (2005) Когнитивные расстройства в пожилом и старческом возрасте.Метод. пособ. для врачей. Москва, 71 с.

13. Марута Н.0., Панько Т.В., Череднякова 0.С. (2008) Клініко-психопалогічні особливості депресій у осіб похилого віку. Міжнар. психіатр. психотер. психоаналіт. журн., 2(1-2): 24-27.

14. Марута Н.О., Ярославцев С.О. (2020) Принципи терапії когнітивних розладів при депресивних порушеннях. Укр. мед. часопис, 6(140). DOl: 10.32471/umj.16803051.140 .193326

15. Федченко В.Ю. (2018) Комплексна система реабілітації депресивних розладів. Вісн. наук. досл., 3: 89-94.

16. Schaffer A., Mclntosh D., Goldstein B.I. et al.; Canadian Network for Mood and Anxiety Treatments (CANMAT) Task Force (2012) The CANMAT task force recommendations for the manage- 
ment of patients with mood disorders and comorbid anxiety disorders. Ann. Clin. Psychiatr., 24(1): 6-22.

17. Morimoto S.S., Alexopoulos G.S. (2013) Cognitive deficits in geriatric depression: clinical correlates and implications for current and future treatment. Psychiatr. Clin. North Am., 36(4): 517-531. DOI: 10.1016/j.psc.2013.08.002.

18. Lorenzetti V., Allen N.B., Fornito A. et al. (2009) Structural brain abnormalities in major depressive disorder: A selective review of recent MRI studies. J. Affect. Dis., 117: 1-17.

19. Батышева Т.Т., Зайцев К.А., Камчатнов П.Р. и др. (2011) Эффективность применения альфосцерата холина (глиатилин) при легких когнитивных нарушениях сосудистого генеза. Журн. неврол. психиатр. им. С.С. Корсакова, 8: 29-32.

20. Бачинская Н.Ю., Копчак 0.0. (2014) Холинергическая стратегия в терапии когнитивных нарушений у пациентов пожилого и старческого возраста. Междунар. неврол. журн., 2(64).

21. Михайлова Н.М. (2016) Применение Глиатилина в стационарном лечении больных деменцией позднего возраста. Психиатрия, 1: 47-63.

22. Muratorio A., Bonuccelli U., Nuti A. et al. (2014) Нейротропный подход к лечению мультиинфарктной деменции с использованием холина альфосцерата. Междунар. неврол. журн., 3(65): 10. https://medi.ru/info/3046/

23. Hamilton M. (1967) Development of a rating scale for primary depressive illness. Br. G. Soc. Clin. Psychol., 6: 278-296.

24. Bueno-Notivola J.,Gracia-Garćáa P., Olayab B. et al. (2021) Prevalence of depression during the COVID-19 outbreak: A meta-analysis of community-based studies. Int. J. Clin. Health Psychol., 21(1): 100196. D0l: 10.1016/j.jijchp.2020.07.007

25. Nasreddine Z.S., Phillips N.A. et al. (2005) The Montreal Cognitive Assessment, MoCA: A Brief Screening Tool for Mild Cognitive Impairment. J. Am. Geriatr. Soc., 53(4): 695-699.

26. Корректурная проба (Тест Бурдона) (1995) Альманах психологических тестов. Москва, 107-111.

27. Бизюк А.П. (2005) Компендиум методов нейропсихологического исследования. СанктПетербург, Речь, $400 \mathrm{C}$

28. Smets E.M., Garssen B., Bonke B., De Haes J.C. (1995) The Multidimensional Fatigue Inventory (MFI) psychometric qualities of an instrument to assess fatigue. J. Psychosomatic Res., 39(3): 315-325. D0l: 10.1016/0022-3999(94)00125-0.

\footnotetext{
Відомості про авторів:

Марута Наталія Олександрівна — доктор медичних наук, професор, заступник директора ДУ «Інститут неврології, психіатрії та наркології НАМН України», Харків, Україна. Явдак Ірина Олександрівна - кандидат медичних наук, доцент, провідний науковий співробітник ДУ «Інститут неврології, психіатрії та наркології НАМН України», Харків, Україна.

Череднякова Олена Сергіївна — молодший науковий співробітник відділу пограничної психіатрії ДУ «Інститут неврології, психіатрії та наркології НАМН України», Харків, Україна.

Адреса для кореспонденції:

Марута Наталія Олександрівна

61068, Харків, вул. Академіка Павлова, 46
}

\section{Treatment of cognitive disorders in depression caused by cerebrovascular pathology: the possibility of influencing acetylcholine neurotransmission}

\section{N.O. Maruta, I.O. Yavdak, O.S. Cherednyakova}

State Institution «Institute of Neurology, Psychiatry and Narcology of the NAMS of Ukraine», Kharkiv, Ukraine

Abstract. In order to assess the effectiveness of the use of the drug Cereglia $^{\circledR}$ (choline alfoscerate) in the complex treatment of depressive and cognitive disorders in patients with stage II dyscirculatory encephalopathy caused by atherosclerosis, a comprehensive clinical and psychodiagnostic examination was carried out (assessment of the depressive state according to the Hamilton scale; mnestic activity according to the method of memorizing ten words by A.R. Luria; cognitive functions according to the Montreal scale for the assessment of cognitive functions; the level of efficiency, concentration and stability of attention using the corrective Bourdon test; the severity of asthenic disorders according to the subjective scale for assessing asthenia (Multidimensional Fatigue Inventory) 60 patients with the indicated pathology. The results of the study prove the high efficiency of the use of neuroprotective therapy (Cereglia $\left.{ }^{\circledR}\right)$ in the complex therapy of patients. It has been shown that the inclusion of the drug Cereglia ${ }^{\circledR}$ in therapy helps to reduce depressive disorders, improve cognitive functions (voluntary attention and mnestic functions), increase the level of work capacity and activity, which confirms the prospects of using the drug in the therapy of this category of patients.

Key words: depression, cognitive disorders, neuroprotective therapy, choline alfoscerate, Cereglia ${ }^{\oplus}$.

\section{Information about the authors:}

Maruta Natalia 0. - Doctor of Medical Sciences, Professor, Deputy director of the State Institution «Institute of Neurology, Psychiatry and Narcology of the NAMS of Ukraine», Kharkiv, Ukraine.

Yavdak Iryna 0. - Candidate of Medical Sciences, Associate Professor, Leading Researcher of the State Institution «Institute of Neurology, Psychiatry and Narcology of the NAMS of Ukraine», Kharkiv, Ukraine.

Cherednyakova Olena S. - Junior Researcher of the Department of Frontier Psychiatry of the State Institution «Institute of Neurology, Psychiatry and Narcology of the NAMS of Ukraine», Kharkiv, Ukraine. Address for correspondence:

Natalia Maruta

61068, Kharkiv, Akademika Pavlova str., 46 